\title{
Editorial for the CEAS Aeronautical Journal special edition on Smart Fixed Wing Aircraft, WP 1.2"Load Control”
}

\author{
Wolf R. Krüger ${ }^{1}$. Jens König ${ }^{2}$
}

Published online: 17 September 2019

(c) Deutsches Zentrum für Luft- und Raumfahrt e.V. 2019

\begin{abstract}
This special issue of the CEAS Aeronautical Journal summarizes articles describing results of the work package "Load Control", which was part of the Smart Fixed Wing Aircraft (SFWA) project, taking place in the framework of the European Clean Sky research programme. The editorial first gives a short overview over the Clean Sky framework and the SFWA project. Second, the articles of the special issue are shortly introduced.
\end{abstract}

This special issue of the CEAS Aeronautical Journal summarizes articles describing some of the outstanding results of the Smart Fixed Wing Aircraft (SFWA) project which took place in the framework of the European Clean Sky research programme.

Clean Sky (CS) is the largest European research programme developing, in the word of its founders, "innovative, cutting-edge technology aimed at reducing $\mathrm{CO}_{2}$, gas emissions and noise levels produced by aircraft" [1]. The programme is coordinated by the Clean Sky Joint Undertaking (CSJU), a public-private partnership between the European Commission and the European aeronautics industry. The first CS programme was running from 2008 to 2016. In the framework of CS, six so-called Integrated Technology Demonstrators (ITDs) were defined, each one co-led by two industrial partners. The largest of those ITDs was the SFWA project [2], co-led by Airbus and Saab. The project had its focus on wing technologies and configurations covering transport aircraft and business jets. One major outcome of the SFWA activities was the so-called Breakthrough Laminar Aircraft Demonstrator in Europe (BLADE) demonstrator, an Airbus project within the framework to flight-test

Wolf R. Krüger

Wolf.Krueger@DLR.de

Jens König

Jens.Koenig@ Airbus.com

1 Deutsches Zentrum für Luft- und Raumfahrt, Institut für Aeroelastik, Bunsenstr. 10, 37073 Göttingen, Germany

2 Airbus Deutschland, Airbus-Allee 1, 28199 Bremen, Germany experimental (natural) laminar-flow wing sections on an A340 from September 2017 onwards [3].

A major field of activity in SFWA was Work Package 1.2, "Load Control", aimed at the investigation of technologies for load reduction for transport aircraft. Four sub-work packages were defined, called "Innovative devices for load control", "Adaptive wing", "Advanced loads control techniques", and "A/C loads evaluation \& optimization", respectively. The articles in this special edition cover work from all of these areas.

Starting partners in the work package "Load Control" were the industrial partners Airbus, EADS-CASA, Dassault and Saab, and the research entities DLR, ONERA, Fraunhofer and Qinetiq. More contributors, notably universities, but also SMEs, joined by means of additional funding calls. In this special edition of the CEAS Aeronautical Journal, we are very happy to present articles by authors from industry, research establishments and universities, notably TU Delft. Several articles feature co-authorships from different entities, documenting the interdisciplinary cooperation grown in the framework of that European project.

A first block of articles describes work on aeroelastic tailoring, i.e. wing design methods utilizing aeroelastic wing properties to minimize loads, and thus wing mass. In the article of Krüger, Dillinger, De Breuker and Haydn, "Investigations of Passive Wing Technologies for Load Reduction" [4], an aeroelastic tailoring framework developed in SFWA by DLR and TU Delft is presented, and results for a long range and a short range aircraft configuration are described. Two articles focus on aerodynamic effects in aeroelastic tailoring_-in Natelle and De Breuker, "The Effects of a FullAircraft Aerodynamic Model on the Design of a Tailored 
Composite Wing" [5], the effects of the aerodynamic model on the design of a composite wing is discussed for the aeroelastic tailoring process of TU Delft. The article of Dillinger, Abdalla, Meddaikar, and Klimmek, "Static Aeroelastic Stiffness Optimization of a Forward Swept Composite Wing with CFD Corrected Aero Loads" [6], presents an approach to introduce CFD-based loads in the aeroelastic tailoring process of DLR for the design of an unconventional aircraft configuration.

In a second block, active load alleviation strategies are discussed. Fezans, Jost, and Deiler show DLR work on "Gust Load Alleviation for a Long-range Aircraft with and without Anticipation" [7], i.e. preview of the disturbance by means of a LIDAR system. Pusch, Knoblach, and Kier, also of DLR, demonstrate options for aircraft design in the article "Integrated Optimization of Control Surface Layout for Active Gust Load Alleviation" [8].

In a third block, developments for different processes and approaches for load analysis are presented. In the article "Examples on Increased-Order Aeroservoelastic Modeling" [9] by Reyes, Climent, Karpel, Arévalo, and Maderuelo, a tool for cases in which the non-linear properties of the aircraft play an important role, or problems where inplane aerodynamic forces should be taken into account, is described. Another presentation of an industrial application at Airbus on the "Developments in Optimized Load Calculation and Extreme Load Detection" [10] is given by Ruiz, García, Hilario, and Calvo. Finally, the set-up and results of a transonic wind tunnel gust experiment at ONERA are illustrated by Huvelin, Lepage, and Dequand in the article "Experimental and Numerical Investigations of a 2D Aeroelastic Airfoil Encountering a Gust in Transonic Conditions" [11].

The editors would like to thank all authors for their contributions and the CEAS Aeronautical Journal for the opportunity to present this compilation.

\section{References}

1. https://www.cleansky.eu/. Accessed 10 Sept 2019

2. König, J., Hellstrom, T.: The Clean Sky "Smart Fixed Wing Aircraft Integrated Technology Demonstrator": technology targets and project status. In: 27th International Congress of the Aeronautical Sciences (ICAS), 19-24 September 2010, Nice, France (2010). https://www.icas.org/ICAS_ARCHIVE/ICAS2010/ PAPERS/288.PDF. Accessed 10 Sept 2019

3. Williams, G.: Aerospace technology demonstration: BLADE, the Flagship Laminar Flow Project within the Clean Sky Programme. SAE Technical Paper 2017-01-2016 (2017). https://doi. org/10.4271/2017-01-2016

4. Krüger, W., Dillinger, J., De Breuker, R., Reyes, M., Haydn, K.: Investigations of passive wing technologies for load reduction. CEAS Aeronaut. J. (2019). https://doi.org/10.1007/s13272-01900393-2

5. Natella, M., De Breuker, R.: The effects of a full-aircraft aerodynamic model on the design of a tailored composite wing. CEAS Aeronaut. J. (2019). https://doi.org/10.1007/s13272-019-00366-5

6. Dillinger, J., Abdalla, M.M., Meddaikar, Y.M., Klimmek, T.: Static aeroelastic stiffness optimization of a forward swept composite wing with CFD corrected aero loads. CEAS Aeronaut. J. (2019). https://doi.org/10.1007/s13272-019-00397-y

7. Fezans, N., Joos, H.-D., Deiler, C.: Gust load alleviation for a long-range aircraft with and without anticipation. CEAS Aeronaut. J. (2019). https://doi.org/10.1007/s13272-019-00362-9

8. Pusch, M., Knoblach, A., Kier, T.: Integrated optimization of control surface layout for active gust load alleviation. CEAS Aeronaut. J. (2019). https://doi.org/10.1007/s13272-019-00367-4

9. Reyes, M., Climent, H., Karpel, M., Arévalo, F., Maderuelo, C.: Examples on increased-order aeroservoelastic modeling. CEAS Aeronaut. J. (2019). https://doi.org/10.1007/s13272-019-00361-w

10. Ruiz, I., García Bosque, A., Hilario Montes, J., Calvo Blanco, M.: Developments in optimized load calculation and extreme load detection. CEAS Aeronaut. J. (2019). https://doi.org/10.1007/ s13272-019-00365-6

11. Huvelin, F., Lepage, A., Dequand, S.: Experimental and numerical investigations of a $2 \mathrm{D}$ aeroelastic airfoil encountering a gust in transonic conditions. CEAS Aeronaut. J. (2019). https://doi. org/10.1007/s13272-018-00358-x

Publisher's Note Springer Nature remains neutral with regard to jurisdictional claims in published maps and institutional affiliations. 